\title{
The Industrious Revolution: A Concept Too Many?
}

\author{
Leonard N. Rosenband \\ Utah State University
}

\begin{abstract}
Much of the recent debate in early modern European labor and economic history has centered on Jan de Vries's concept of the industrious revolution. Briefly, he claimed that workers during the period 1650-1800 chose to labor longer hours, often at greater intensity, in order to consume novel manufactured goods and imported commodities. Moreover, plebeian families increasingly pursued new employments beyond the household to pay for these objects. As a result, men, women, and children spent ever more hours in waged labor, and their growing purchasing power proved decisive in stimulating large-scale European industrialization. My work on the history of French and English papermaking raises fundamental challenges to this model. First, paperworkers already labored exhausting hours at the outset of de Vries's period of newfound industriousness. Second, masters and workers alike knew that they had to both "speed up" and "take their time" to turn out quality paper at the expected rate. Third, women and adolescent workers toiled for wages in paper mills long before the seventeenth and eighteenth centuries. On the eve of large-scale mechanization, enduring shopfloor realities, skills, and quotas prevented a surge of productivity beyond papermaking's familiar standards. With the demand for paper rising rapidly, it was the absence of an industrious revolution in papermaking that turned the manufacturers' attention first to enlarged mills and small technological shifts, and finally, to the development of a papermaking machine.
\end{abstract}

\section{Introduction}

A sheet of fine paper made in the eighteenth century possesses a timeless beauty. Whether white printing paper or light blue stationery, it was at once durable and ephemeral, elegant, and subtly flawed. It took months and the touch of as many as twenty pairs of hands to transform cast-off linen into cheap brown paper or high-quality reams. For the manufacturers, best practice was to stimulate paperworkers to "hurry up and take it easy" while fashioning easily ruined sheets. ${ }^{1}$ This balance formed the core of both the entrepreneurs' and the journeymen's understanding of industrious work. Here was a formula to ensure the producers' sales and solvency, if not windfall gains. For the journeymen, a practiced awareness of the trade's sense of a full day's output was a passport from mill to mill, as well as the means to keep a lid on a new boss's expectations. While masters and men did not meet on a level field, both sides valued a certain predictability and the security it might promise, especially in the face of frequent breaks in production and occasional downturns in demand. Of course, the arrangements between masters and men evolved, with wages proving considerably more unstable than output quotas. (As a rule of thumb, the entrepreneurs and the workers were well aware that the 
reward for a week's worth of a skilled man's toil equaled the price of a single ream of good paper.) Small wonder, then, that in early modern European papermaking, the manufacturers and journeymen always put a premium on the command of work, its time, and its compensation. They could ill-afford to follow any other course.

The economic historian Jan de Vries coined the term "industrious revolution" in a series of remarkable articles and a synthetic volume that appeared in 2008. ${ }^{2}$ He argued that the laboring poor often lengthened their working hours and toiled with greater intensity during the long eighteenth century (16801815 ) in order to expand their purchasing power. What they bought was a wide and frequently new array of manufactured consumer goods and imported commodities. But de Vries's attention to the working hours and efforts of these men, women, and children did not originate from consideration of workshops and their routines. Instead, he was fascinated by the role of rising consumer demand in the coming of the industrial revolution.

In this essay, I explore de Vries's account of the nature and roots of the industrious revolution by locating it within the rewards and frustrations of making paper by hand. Above all, my work reveals the everyday experiences and labor of the master papermakers and journeymen that gave rise to their distinctive assumptions about and patterns of industriousness and, hence, to their particular habits of calculation and consumption. Although this essay emphasizes the circumstances and trajectories of the trade in France and England, it also depicts practices and developments in American, Austrian, Danish, Dutch, Polish, Spanish, and Swiss papermaking. ${ }^{3}$ It could not be otherwise, since the essential skills, work, customs, and technology of the industry had spread widely across early modern Europe and the Atlantic. So, too, had the hours for the start of work - midnight to 3:00 or 4:00 a.m. in most places, with English journeymen alone beginning at 6:00 a.m. Downtime and overtime payments, as well as the number of reams in a standard day's labor, were also woven into the craft from El Paular to Kent, and from Ambert to Rannersdorf. ${ }^{4}$ Even in the midst of the rising demand for paper in the eighteenth century, it was the daringor foolhardy-papermaker who tried to extend the workday, raise daily quotas, or shift mealtimes.

Hand papermaking offered little opportunity for the "improving" manufacturer who wished to craft and conduct a revolution in the industriousness of the workers who sweated in his shops. After all, the grueling workdays of the journeymen-usually twelve hours, but in a few places as many as fourteen-left limited space at the margins of routine production for newfound industriousness, as did six-day workweeks. As spiraling demand met output ceilings, manufacturers built more mills or added more units of production to ongoing enterprises. But the journeymen paperworkers had labored long and hard to keep their ranks thin, familial, and carefully initiated in their custom. They were not about to sacrifice the "goods" of access to employment for their sons and themselves or familiar customs and quotas for the pleasures of tea and razors. When their sense of the proper order of the trade was 
threatened, they withdrew their labor, a tactic rendered especially effective by the speed at which the pulp declined. For their part, the manufacturers turned to states everywhere during the eighteenth century for aid in governing these ungovernable journeymen. And they longed for a machine that would replace their skilled, industrious hands.

De Vries was drawn to the workdays and exertions of the early modern European laboring poor by the intersection of two, seemingly contradictory patterns. ${ }^{5}$ First, he recognized that historians of the English industrial revolution maintained that the wages of most workers in newly industrializing England remained stagnant at best and, in many cases, deteriorated. Furthermore, these English wages, along with those of the Dutch laboring poor, were the highest in eighteenth-century Europe. De Vries reasoned that plebeian consumption should have been constrained, and the goods used by working families should have been primarily the products of their own hands. But when scholars turned to probate records, they discovered that Europe's lower ranks enjoyed an ever-widening array of consumer goods and, most notably, that these items were not manufactured by the consumers themselves. As Cissie Fairchilds explained, many of the products were "populuxe" goods - that is, knockoffs of the fine wares acquired by the upper ranks. ${ }^{6}$ Still, it was the novelty of both the depth and breadth of this newfound access to umbrellas, watches, snuff boxes, and the like that mattered. And stimulant beverages, tobacco, and other perishable items from abroad hardly figured in the inventories of goods. How, then, to reconcile stagnant wages and the laboring poor's purchase of an unprecedented abundance of manufactured and imported products?

De Vries found his answer in a fresh "disposition" among the working poor. ${ }^{7}$ Laboring men chose to devote more hours to paid employment and to intensify their efforts at work in order to satisfy their recently acquired tastes. Wives and children also shared this novel disposition and participated more frequently in "market-oriented labour," namely, paid work, often outside the household. ${ }^{8}$ Whether the women and their offspring turned out textiles in their cottages or secured waged work in mills, fields, or commercial services, they were increasingly ensnared in the great transformation of consumption. ${ }^{9}$ As these plebeian households became more elastic suppliers of labor and more compulsive consumers of tangible goods, traditional patterns of leisure preference also diminished. For de Vries, however, this important trend in the tradeoff between labor and leisure was overshadowed in significance by the "reallocations of the productive resources of households" from largely selfsufficient production and consumption to more hours of paid labor. ${ }^{10}$

With newly fattened purses, the laboring poor added their purchasing power to that of the eighteenth century's proverbially rising bourgeoisie. According to de Vries, this mix created the first effective demand-side "setting" for the supply-side transformations known collectively as the industrial revolution. ${ }^{11}$ Moreover, this moment of modernization was natural and innocent, the result of choices by working families themselves rather than the outcome of external exactions by employers, the law, and "preachings and 
schoolings." 12 A virtuous circle was rapidly closing. But this circle remained open and unfinished in one of early modern Europe's most prominent and widely diffused production sites-paper mills. There journeymen had adapted over centuries to lengthy, intense hours of labor. And there women and adolescents had always filled roles in the production process, earned wages (and sometimes bonuses), and toiled as long as production seasons lasted. Neither an industrious nor a consumer revolution first drew entire households into these mills. Nor did these "revolutions" transform the imperatives that shaped productivity in the craft.

As de Vries noted, many historians who failed to share his vision of the utility of the concept of industrious revolution still found that the temps de travail had grown longer for many during the eighteenth century. In his justly famous essay on the persistence of customary workloads, E. J. Hobsbawm concluded that Old Regime employers trusted in extensive exploitation in the form of increased hours and fixed or even lower wages to secure greater output. (Rising population, bad harvests, and elevated grain prices after 1750 had rendered the employers' strategy feasible.) Hobsbawm found compulsion where de Vries located choice. A more humane intensification of work, Hobsbawm maintained, largely awaited nineteenth-century experiments, when manufacturers attempted to raise productivity through some combination of payment by results, higher wages, and shorter hours. ${ }^{13}$

According to Sidney Pollard, the issues facing the masters and manufacturers who dreamed of increased output were doubly complex. Whether they depended on skilled or unskilled hands, he claimed, these employers had to turn laborers accustomed to bouts of irregular toil and the sustenance it provided into persistent, regular producers who sweated for greater purchasing power. As Pollard phrased it, "men who were non-accumulative, nonacquisitive, accustomed to work for subsistence, not for maximization of income, had to be made obedient to the cash stimulus, and obedient in such a way as to act precisely to the stimuli provided."14 This is a powerful, evocative passage. But like de Vries's and Hobsbawm's accounts, Pollard's discussion rested on limited attention to the intrinsic qualities of the work and the singular shop-floor practices that distinguished every sector of early modern industrial production. Certainly, emphasis on a particular sphere of manufacture courts the historiographical risk of obscurantism, of building explanatory mountains out of molehills. It is therefore worth observing that paper mills, arsenals, potbanks, and shipyards, as well as some breweries and glassworks, shared several characteristics. They were capital-intensive production sites, housed a considerable number of tools and small machines, and depended on journeymen, women, and children playing their parts in extensive divisions of labor. None of these features constituted a new organization of production during the long eighteenth century.

For the cottager's son seeking a spot in a paper mill, the pace and the close coordination of the work must have seemed unsettling, even daunting. But for the seasoned paperworker, who stood on the shoulders of generations of 
ancestors in the trade, the bustle and integration of the toil was second nature. Long before the onset of large-scale mechanization, journeymen paperworkers had left behind the supposedly "natural" rhythm of labor and leisure in artisanal and agricultural toil for the rhythm of industrial production. They labored strenuously to preserve a just "day's work," the complicated system that combined the established hours of labor with production quotas and premiums for the completion of the regular workday. They also enjoyed rewards for habitually performed tasks, such as clearing the leftover pulp from the molds.

Before the long eighteenth century, paperworkers knew the value of every moment of their labor and contested every effort to lessen it. They were hardly innocent of the fresh routines of industrial time and far from the ranks of the "labouring poor" who "said little," as David Landes would have it. ${ }^{15}$ Instead, they labored noisily and industriously to protect the payments and customs that comprised the wage system, a subtle blend of deeply entrenched bargains between the journeymen and masters about skills, responsibilities, and hours. At the very least, close inspection of this wage structure brings us nearer to the actual world of work than the observations of the Enlightened economist James Steuart, who thought that the seductions of consumption had replaced coercion as the most efficient tool to secure greater effort among the laboring poor. ${ }^{16} \mathrm{He}$ maintained that "Men are forced to labour now because they are slaves to their own wants." 17 (Of course, had he noticed the intangible "goods" that motivated the journeymen paperworkers, he would have dismissed them as "antique customs" or blind routine, as did contemporary French paper manufacturers. ${ }^{18}$ )

Too often the study of early modern European industrial worktime and productivity turns on consideration of metaevents and metathemes. It emphasizes the Reformation and the rise of a distinctive Protestant work ethic; the slow but critical transformation in the workers' supply of energy, especially in Holland and England as a result of their "escape" from the prison of hunger; the emergence of a dominant mode of interpretation, the Enlightenment, capable of thoroughly remaking production; and now, the appearance of an ostensibly novel plebeian culture of industriousness and acquisitiveness, particularly but not uniquely in Protestant northern Europe. ${ }^{19}$ But comparative inquiry into a widely diffused trade, such as papermaking, can offer a different picture. Despite the Reformation and the Protestant ethic, English paper manufacturers, latecomers to the production of fine reams, had a great deal to learn from their French counterparts. ${ }^{20}$ Moreover, in the twilight of the Old Regime, paperworkers on both sides of the Channel sweated to meet the same customary expectations for their daily output. And they paid for their living in Maidstone as well as in Annonay with lost fingernails, lethal illnesses, and long hours. To understand their willingness (or desperate need) to do so, we must turn first to the shopfloors, work practices, and wage systems of their trade. Only then can we explore the comparative influence on their workdays and workyears of such matters as national and religious cultures, political institutions and policies, and desires to consume fresh enticements. 
By considering how masters and men managed the hours of labor, expectations about output, and diligence that characterized Old Regime papermaking, this essay returns the shopfloor pressures and the experience of work itself to the core of the issue of industriousness. It begins with an analysis of the time-sensitive, easily disrupted process of crafting five or six reams of paper per day. Next, I turn to the endless array of threats to the regular production and marketing of paper, from fires, freezes, and droughts to larcenous teamsters, wartime blockades, and foreign competition. Not surprisingly, many master papermakers found reliable profits hard to secure; bankruptcies were frequent. So these producers hedged their bets by taking advances from printers or stationers who, in turn, agreed to take the papermakers' annual output before the vatman had lifted his mold. (Here was a key reason why paper manufacturers were especially attentive to the hours and productivity of their hands.) To avoid the common pitfall of failure, the manufacturers sought premiums and protection from states, engaged in (largely second-tier) technological improvement, and competed feverishly to hold onto familiar customers and land new ones. (Enterprising manufacturers were quick to send quires and even reams to printers and stationers for inspection, and it is these unmarked sheets that collectors of fine paper seek today.) No holds were barred, including the adulteration of sheets with artificial whiteners, in the pursuit of profits in this internationally competitive industry. ${ }^{21}$

For their part, the journeymen and their families also tried to master the vagaries of their trade. Consequently, much of this essay explores the terms they enforced for tramping, a routine passage in every paperworker's life, their efforts to control the market for their skill, and their notions of the good life, from the food they expected at the "master's table" to the holiday downtime and delicacies they enjoyed. Beyond the conventions they negotiated with their masters, the journeymen also manufactured their own custom, which they deployed with singular success despite the curses of their employers and bans issued by states. They labored tenaciously to retain the trade's time-honored wage systems and output schedules, even as their human foibles - a cough or an indifferent slip-marred a sheet or two. Their industriousness was not new in the long eighteenth century, which is one reason why rising demand for their product mattered so much to their masters. Here, then, was the precise connection between demand- and supply-side industrial revolution that de Vries sought. This link was forged in traditional skills, patterns of work, and consumption, rather than a fresh burst of industriousness.

\section{Making Paper and its Discontents}

Hand paper mills generally had two stories. On the ground level, discarded linen, unraveling ropes, and stained, torn sails were sorted, paper was made, and newly minted sheets were glazed. The creaking of carts loaded down with baskets of these dusty and sodden materials signaled the beginning of the papermaking season. A typical French mill housed only one production vat but 
consumed three hundred quintals of rags every year. Since France had about nine hundred paper mills in 1788, its national industry required a mind-numbing amount of cast-off linen and other fibers. ${ }^{22}$ The rag merchants who brought the discarded linen to the mills knew they had a valuable commodity. In 1784-1785, James Whatman II, England's premier papermaker, observed that rags accounted for 47.5 percent of his production costs. Twenty years earlier, Georg Keferstein, a German manufacturer, found that discarded linen amounted to thirty-eight percent of his production outlays. At the same time, the wages Whatman paid added up to fourteen percent of his expenses, while Keferstein's expenditures for labor reached twenty-one percent of his total outlay. ${ }^{23}$ Before large-scale mechanization, materials were inevitably more expensive than men, including the skilled.

The division of labor and basic manipulations of handicraft papermaking were alike in mills throughout Europe. Effectively, production consisted of three stages: the rotting and mechanical reduction of cast-off linen into pulp, the creation of the paper, and the preparation of the infant sheets for ink and transport. Female hands initiated the work. They divided white rags from gray, removed caked dirt, and cut away matted patches. If their work was hasty or indifferent, they could damage the pulp, so the master papermakers of Berne prescribed the maximum weight of rags they should "cut" each day. ${ }^{24}$ An experienced man watched over rows of stamping mallets that separated the linen, already weakened by a customary period of fermentation, into cellulose filaments. He knew that the fermentation had proceeded long enough when he could feel the proper degree of heat in a handful of pulp. Next, the vatman evaluated the color and consistency of this material, the surest guide to the final weight of the ream. Then he dipped his mold, a rectangular, wire mesh bounded by a wooden frame, into a tub partially filled with warm, watery pulp. He lifted the mold quickly and shook it in a time-honored pattern so that the fibers of the infant sheet "shut." Depending on the scale of the mold (and hence the size of the paper), he generally performed this task about three thousand times per day. The vatman then passed the mold, with the fresh sheet clinging to its wires, to the coucher. This craftsman's main tool was a stack of hairy felts, which he rested on a small easel. He needed steady hands and good timing, since he flipped six or seven sheets of paper per minute from wire to felt. Once his pile of woolen felts, each now bearing a moist sheet of paper, reached a certain height, it was known as a post. Then it was pressed.

The layman separated the paper from the felts, a delicate task. ${ }^{25}$ More pressing followed and the sheets were draped over cords to dry. The sizerman collected the still moist paper and immersed it in an emulsion of hides, hoofs, tripe, and alum. This gelatin bath filled the paper's pores, thereby preventing ink blots. The sizerman tested his work with his tongue: if it left a balanced impression that resembled a fan or a butterfly's wing on the sheet, the finish was good. Finally, women smoothed and sorted the paper, excised stained and clotted swatches, and assisted the loftsman in wrapping the reams. Though 
rich in custom and lore, papermaking was always a precise industry. The romantic image of the languid, self-directed pace of the independent artisan misses much of the activity in premechanized paper mills. Here "factory artisans" labored at closely integrated tasks. Although certain hands still exercised some control over the rhythm of their toil, the lowly apprentice who failed to stir the pulp at the base of the vat at regular intervals put the quality of the paper at risk. If the supervisor of the stamping mallets failed to rouse himself from sleep during heavy rains, turbulent, muddy water flooded the troughs and discolored the pulp. Exacting time-discipline had always been a feature of papermaking; its presence showed in every sheet. Moments mattered. There was little available production time for the "extensive" coercion emphasized by Hobsbawm or the lengthier hours of labor that de Vries claims newly industrious workers increasingly chose.

There was money to be made in the manufacture of paper. In 1761, the astronomer and technical writer Joseph-Jérôme Lefrançois de Lalande noted that paper had become "an everyday merchandise." ${ }^{26}$ He offered two assessments of the annual expenses and upkeep of a French paper mill. The manufacturer would net 5,986 livres tournois in one fanciful audit and 3,231 in the other. These were handsome, if not princely, returns. But Lalande's wishful calculations were based on the production of three thousand reams of paper during an impossibly optimistic year's work of three hundred days. ${ }^{27}$ So, too, were the estimates of a later scholar who maintained that the papermakers of Old Regime Austria annually furnished 1,800 reams of large paper or 3,600 reams of small sheets. ${ }^{28}$ Thus the cautionary voice of the experienced economic historian Carlo Cipolla, who wrote that the one-vat mills of seventeenth-century Italy furnished a "maximum" of 4,500 sheets of paper per day, but made no claims about annual output. ${ }^{29}$

Successful production turned on timely weather, a full storeroom of old linen, accessible markets, the absence of catastrophic disruptions, and a ready supply of skilled journeymen. Few manufacturers could count on all these assets for very long. More typical were the troubled circumstances of the papermakers of Languedoc, according to a survey from 1772. A manufacturer in Le Vigan reported that one of his vats "had been idle for a long time for want of [raw] materials." A producer in Cavaillac claimed that "this mill only works for 6 months of the year for want of water." A papermaker in Joyeuse lamented that "these mills would work profitably if they were busy all year." But they ceased making paper for three months each year due to "droughts and inundations." The waters of the Tarn River, which "are dirty most of the time," produced "un chômage considérable" in the mills of Mazamet. At Castres, the manufacturers suffered "considerable prejudice" to their interests because "merchants, mercers, and colporteurs" illegally exported discarded linen. So it went for page after page in the enquête. Seeking relief from the onerous paper tax the Crown imposed in 1771 and probably petitioning indirectly for state subsidies, the papermakers may have underestimated their output and production seasons. ${ }^{30}$ Yet it was the 
rash paper manufacturer who turned to Lalande's estimates as a reliable guide for his annual profits.

Fire and floods consumed paper mills and profits all too often. In 1756, for instance, flames "entirely reduced" a mill in Eynsham "to a heap of rubbish."31 Surrounded by hills of rags, stuffed with paper and chemicals, and dependent on warm pulp and heated size, paper mills burned quickly. Angry journeymen and jealous competitors knew the vulnerable points. "Some villains set fire" to an enterprise in Surrey in $1774 .^{32}$ Meanwhile, papermakers also fiercely guarded their access to limpid, fast-flowing streams. But the active headwaters ideal for making paper also carried the threat of floods. In 1713, "a very great floud" devastated the holdings of John Wood, a papermaker in Uffculme. Wood and his family narrowly escaped drowning, "ye house and mill being almost destroyed." This perch and its waters, however, were too tempting to abandon easily; it was only in 1753, when "Part of the Paper Mill house fell during a great flood" that the site stopped furnishing paper. ${ }^{33}$ Small wonder that so many paper mills proved to be disastrous investments and that both ownership and leases on mills rapidly changed hands.

In 1781, a paper mill damaged by an earlier torrent was described as "quite Rund down and become quite Ruinous and perfectly decayed and not worth repairing." 34 Maintenance was never the greatest expense borne by hand papermakers, but it took its toll, as did its neglect. Papermakers understood that a declining plant produced reams of diminished quality. A warped waterwheel yielded less power, and molds with loose and broken wires harmed infant sheets. Nevertheless, most Old Regime paper manufacturers "operatedto-failure." They were slow to refurbish their equipment, and often failed to remedy problems until the imminent sale of the mill compelled repairs. As Denis Woronoff suggested, this neglect may have served as a functional equivalent to obsolescence, opening space for fresh tools and techniques. For many papermakers, however, it was simply an instrumental way to expand their profit margins. $^{35}$

Even the producers of cheap wrapping paper depended on nimble vatmen and sober sizermen. Yet the journeymen paperworkers of France had crafted a colorful vocabulary for the flaws they left in the paper: châtaignes (chestnuts) for splashes of pulp; pieds-de-chèvres (goat's feet) for pinches and wrinkles; and andouilles (sausages or even shits) for clotted areas. And a Danish manufacturer, whose equipment was reputedly in "excellent condition," informed officials in 1753 "that for many years he had annually produced two hundred reams of writing [paper], seven hundred reams of printing [paper], and fifteen to sixteen hundred reams of low-grade." 36 Shortages of fine rags as well as fine hands had resulted in this balance. Haunted by the same problems, as late as 1782, the Welsh and the rapidly improving English industry together produced 480,000 reams of brown or whited-brown paper out of a total of 900,000 reams. ${ }^{37}$ Though highly skilled, French workers in 1788 still "broke" ten percent of the sheets they turned out, especially if a clumsy layman was afoot. Consequently, a commercially acceptable ream of French paper continued to 
include eight quires of first-class paper, known as bon, eight quires of secondclass retrié, and four quires of badly marred chantonné. ${ }^{38}$

Surprisingly, the Languedocian manufacturers' litany of complaints did not include the usual grumbling about footloose, irresponsible journeymen. But short papermaking seasons shed new light on the workers' alleged shortcomings. Since stability of employment often proved elusive, the journeymen became accustomed to the privations as well as the temptations of the road. Even the fortunate worker's time with a congenial employer ended abruptly with a flood or a rag famine. So the masters' routine charges of fecklessness and sloth look different in the shadow of unsteady employment. In the midst of flush times and punishing days of labor, why not enjoy a day or two at the tavern or brothel, an experienced journeyman might ask. ${ }^{39}$ Such calculation inevitably enraged the masters, who wanted men ready at opportune moments and the freedom to discard them in tough times. But the rising demand for paper during much of the long eighteenth century allowed the journeymen to defend both familiar pleasures and patterns of productivity. A supply-side solution-a papermaking machine-would enable the manufacturers to displace both and produce vast numbers of sheets without traces of a sneeze or shaky hand.

\section{Leaders and Followers}

Europe's master papermakers and journeymen were ruled as much by the longterm directions and dramatic fluctuations of their national industries as by fragile papermaking seasons. At various times, the leading producers were centered in Fabriano, the Auvergne, and Zaandam. Unlike the case in several industries, at no time before 1800 could England's manufacturers claim primacy in the production of paper. Like their Continental competitors, they remained locked into the long-standing wage system and production quotas of their art. And they, too, lacked the technological means to overturn the powers and practices embedded in the journeymen's skills.

The rise of white paper production in England was relatively rapid and late. About 100 mills furnished around 2,500 tons of paper early in the eighteenth century. Just before Christmas in 1697, the Commissioners for Trade and Plantations declared: "We humbly conceive it is also a very usefull Manufacture deserving all incouragement, and that we may improve to make as good as what comes from abroad." ${ }^{40}$ Not surprisingly, changes in England's works depended heavily on the arrival of French and Dutch producers and journeymen. After the revocation of the Edict of Nantes, Huguenots in flight transferred the techniques and touch of the French trade to England. In 1718, it was said that "much the best Printing Paper in England is made at Southampton by a Frenchman," probably Daniel Roussillon. ${ }^{41}$ Inevitably, the journeymen paperworkers who improved the English art also transported their customs, their expectations, and their sense of a proper day's output across the Channel.

The improvement of English papermaking turned on protection and promotion by the state. As D. C. Coleman observed, "the paper industry grew up 
in the eighteenth century as an extremely sheltered industrial child."42 Above all, in 1712, Parliament levied a stiff customs duty on imported reams. The ratio between this impost on foreign paper and the lighter burden placed on the home industry aided the maturation of English papermaking and its convergence with its Continental competitors. Still, as late as 1738 , the Commissioners of Excise affirmed that at least three-quarters of England's mills furnished coarse reams. ${ }^{43}$ Meanwhile, improving English manufacturers increasingly took advantage of a Dutch device for the preparation of the pulp. From the 1670s, Dutch papermakers relied on the Hollander beater (or "engine") to shred cast-off linen. A rotating gauntlet of opposed metal in an oval tub, this device required less space, supervision, time, and water power than the stamping hammers. It worked with fresh rags, which conserved linen and produced a pulp of shorter, more uniform fibers, the secret of the supple firmness of Dutch paper. So the manufacturer who possessed this instrument almost certainly enjoyed lengthier production seasons. Additionally, the Dutch practice of preserving some dampness in the drying sheets and shuffling them under the press did not disturb the grain as much as French trip-hammers and smooth stones. With a bit of bluing already added to the pulp, the lustrous, faint blue paper furnished by the Dutch proved irresistible.

In the 1730 s and 1740 s, two progressive Irish producers resolved to construct "a new Mill after the best Dutch Manner." "44 Hollander beaters spread across the English industry from about 1750, and by 1800, it was thought that only a single English mill still resorted to stamping hammers. English papermakers likely enjoyed Gerschenkronian advantages, the openness and the desperation of the latecomer, in their relatively rapid adoption of this machine. ${ }^{45}$ Their countrymen's advanced metalworking skills were also critical in the successful embrace of the beaters, while the disturbances in international trade caused by the midcentury wars strengthened the position of England's papermakers in the home market. Yet, their perch remained precarious: An assessment of the English industry in 1747 claimed that "[w]e are but lately come into the Method of making tolerable Paper; we were formerly supplied with that Commodity from France, Holland and Genoa, and still are obliged to these Countries for our best Papers."46

By the 1770s and 1780s, English manufacturers produced substantial amounts of fine stationery and printing paper. But the industry also suffered from the downside of Gerschenkronian advance. Making better paper required more fine linen as well as men with refined skills. Nevertheless, paper production in England increased fourfold from 1738-1800, while the number of mills only doubled, probably as a result of the virtues of the Hollander beater and the furnishing of more mills with two and even three production vats. It should have been the best of times for England's papermakers, and in some ways it was. But the shelter the trade had long enjoyed was cracking. Serial increases in the excise duty on paper resulted in an eleven-fold hike in the amount paid between 1775 and 1800, a far greater surge than in paper production itself. Whatman, who produced about 8 percent of England's fine paper, saw the 
take of the excise rise from 4 percent of his expenses before 1781 to 21.5 percent in $1785 .^{47}$ England's producers remained both proud and uncertain about the competitiveness and quality of their reams. The paper hangers and manufacturers were loud, apprehensive opponents of the negotiations to lower Anglo-French trade barriers in 1786. While sizing up the French and English goods that would prosper or suffer under the treaty, William Pitt cautioned that " $[\mathrm{t}]$ here are some other articles, such as hats, paper, leather, etc., on which it is perhaps doubtful which way the advantage would lie."48 Meanwhile, the journeymen had mastered the art of the rolling strike. Like the manufacture of quality paper itself in England, the journeymen's militance developed late. But now their sense of the worth of their increasingly skillful work dovetailed with that of their Continental counterparts.

In 1669, French papermaking consisted of about four hundred paper mills. (France had yet to absorb certain provinces that also furnished a considerable number of reams.) On the eve of the French Revolution, the industry probably housed as many as one thousand production vats; but this growth was hardly linear. ${ }^{49}$ As late as 1669, France's manufacturers dominated their home market as well as the international trade in fine paper. That soon changed: War and the emigration of many Huguenot papermakers and journeymen badly damaged production. By 1717, two-fifths of the paper mills in the Auvergne, France's foremost papermaking region, were shuttered. Uneven recovery followed, in part because the manufacture of paper was widely diffused across France and each region had its particular specialties, aptitudes, and customers. France's preeminence in the international market for paper had ended, and the revival of the industry increasingly depended on domestic consumption.

To restore French papermaking, the Crown turned to elaborate regulation. It announced highly detailed standards for the tools, techniques, and time of production in 1739. Two years later, it added precise standards for the weights and measures of every sort of paper. Of course, masters faced with the alternatives of punishment or the disappearance of a customer made a calculated choice: They "preferred to cross the law rather than their interests or those of their mill."50 For the tough-minded manufacturers whose daily production was an adventure, this decision was inevitable. Thus, the state's attention increasingly turned to remaking the technology of France's paper mills. In this pursuit of improvement, a complex pattern of reciprocities emerged among the entrepreneurs, provincial authorities, and Enlightened bureaucrats within the central state itself.

The early French use of Hollander beaters failed. The device required a precise fit between metal blades and the bedplate, but wooden wedges, the initial artifice of French papermakers, yielded inferior pulp and paper. Evidently, maintenance costs continued to be higher for these French engines as well. As a result of some industrial espionage engineered by the French state in 1768 , the Dutch beaters finally found a working role in French papermaking in 1780 . Nine years later, the thump of these engines could be heard 
in more than a hundred mills in fourteen généralités. ${ }^{51}$ The failed Tocquevillian "dirigisme" of 1739 and 1741 gave way to successful state promotion of an advanced device that furthered the interests of private producers. In the last decades of the Old Regime, these private producers certainly turned out more paper: In 1776, the output of Ambert's important industry was "without precedent." 52 At a more intimate level, writing tables turned up more frequently in post-mortem inventories in pre-Revolutionary Paris. ${ }^{53}$

To the manufacturers' chagrin, this increase in the consumption of paper at the close of the eighteenth century was accompanied by both steady increases and sharp spikes in the cost of linen and labor. As a result, many French and English producers still struggled with solvency while longing to join the charmed circles of the trade. But an inexpensive substitute for discarded linen had yet to be found, and the balloonist and papermaker Joseph Montgolfier's wooden automata failed to replace the vat crew. The manufacturers endlessly bemoaned the costs of ungovernable fire and rain, but they strained mightily to govern the cost of the journeymen's labor.

The workers on both sides of the Channel were of another mind. They took advantage of their scarce skills to secure higher wages at a time of heightened demand for paper, just as French workers had during the good times of the seventeenth century and even occasionally during the hard times in between. For example, in 1600, the master papermakers of Vieux-Thann and Cernay, in Alsace, raged about journeymen who wanted their wages doubled. (The "always insatiable" workers were also "never satisfied with the food that is served them," according to their aggrieved masters. ${ }^{54}$ ) In 1634, the master papermakers in the vicinity of Marseilles agreed that they would no longer lure journeymen from each other's mills. The temptation had been the offer of higher wages. ${ }^{55}$ But the journeymen also knew that if a stream dried and a production season ended, even in the best of times their work and wages would dry up as well. So they pressed for lofty pay and overtime premiums whenever they could and enjoyed these flush times for as long as they lasted, because they had learned that lean times were inevitable. And while they bargained for increased wages, they gave no ground on their customary "day's work." In France, England, and elsewhere, the industry had traveled separate roads to the same point.

\section{Custom, Wages, and Workload Revisited}

In early modern England, papermaking was a capitalist industry clothed in a corporate idiom. It was never characterized by E. P. Thompson's moral economy of the marketplace or de Vries's depiction of worker households moving from contact with the market to orientation to it. ${ }^{56}$ After all, papermaking families had always fashioned reams for markets near and far rather than for their own use and depended on wages for the goods they purchased and consumed. Yet, on the eve of the full mechanization of production, the trade still recognized masters, journeymen, and apprentices, and set standards for proper entry into each rank as well as routine passages up the craft ladder. 
The French industry lacked formal guilds to oversee all this and English papermakers ignored the Statute of Artificers (1563). Nevertheless, manufacturers and workers throughout Europe and across the Atlantic continued to express their mutual interests and practices in the language of custom, and the journeymen still appealed to the authority of their self-styled conventions when they confronted the masters. For instance, in 1787, a French magistrate denounced Swiss and German paperworkers for importing their "abusive ways" into his country's trade. ${ }^{57}$ These customs, of course, were long familiar on his native turf. The American papermaker Zenas Crane honored the transnational ways of his trade in 1820 by providing traveling journeymen "with a meal, a bed for the night, a quire of broken paper, and a parting dram of spirits if no job was forthcoming." ${ }^{, 58}$ As late as 1858, a departing worker in England left behind a gold guinea, or a producer bent on dismissing him put one in his pocket. This was a practice from the era of hand papermaking, when a guinea approximated two weeks' worth of work by a skilled man. Taken together, these anecdotes reveal that both the trade's contested traditions and those shared by masters and men were persistent and portable. Doubtless, these practices sometimes mutated as they migrated across the Atlantic, the Channel, or even regional boundaries within France. But the journeyman exiled by a manufacturer as a result of his loyalty to the workers' customs would likely find his swagger rewarded and his fear assuaged by work elsewhere.

To preserve their versions of the bon ordre of the trade, manufacturers and workers resorted to mirrorlike tactics: The patrons withdrew their capital, and the journeymen withdrew their labor. Considering the challenges the manufacturers faced in gathering all the resources required for the production of paper, the workers' strikes - and even the threat of a walkout - were highly effective. So were the masters' lockouts, particularly when they were coordinated and shuttered several mills. Time on the road had its seasonal pleasures, but it also entailed cold, thin purses, and hungry children in tow or, more often, left behind. Masters and workers, then, knew the price of time without work as well as the value of strenuous labor and its products. The conceptualization of time as money, at least in papermaking, took root long before the mechanization of the art, not as a result of it. If access to new "populuxe" goods intensified this understanding, it, too, did not forge this link.

Ever fearful that papermaking profits (and the government's revenues) would be compromised by journeymen on strike, on the move, or merely asleep at a tavern, the French state issued a sweeping edict in 1688. (Such actions, of course, usually target long-standing, widespread practices.) This decree was meant to end a work stoppage by prescribing the rights and responsibilities of masters and men, including the amount of paper each vat crew was to furnish every working day. ${ }^{59}$ At the time the edict appeared, French paperworkers were said to put in workdays of twelve hours; remarkably, Auvergnat paperworkers actually began their labor at midnight or 1:00 a.m. and finished when the "day's work" was done "around noon or an hour later at most." 60 Dressed in customary costume, arms reddened by dipping their molds in 
warm pulp, and surely singing and shouting along the way, they must have enjoyed their midnight marches to the mills. But no convincing, comprehensive argument has been made to explain why the journeymen commenced their toil in the middle of the night. Reserving daylight for labor in the fields or attendance at the confrérie seem to be insufficient reasons for night work. Did journeymen simply want to escape frigid winter nights in small lofts or the heat of summer days? Their masters, who raged against this custom, worried about the cost of candles, the threat of fire, and the theft of rags and reams.

The grand edict of 1739 found a Solomon-like solution: It mandated that the journeymen put in half of each workday before and after noon and that work around the vats was not to begin before 3:00 a.m. ${ }^{61}$ How frequently this new schedule was honored is beyond our knowledge, but a strike by the journeymen paperworkers of Thiers (in the Auvergne) is illuminating. In 1772, the master papermakers of the town, eager to economize on their costs, decided to move the start of work closer to sunrise. This difference of one hour evidently made all the difference to the workers. They walked out en masse and quickly won the day: Work continued to begin at 3:00 a.m. ${ }^{62}$ Yet it is difficult to imagine that many masters trusted in the combination of a 3:00 a.m. start and sustained production after noon. Would the journeymen return after they laid the molds down and in what condition? Would the pulp turn or congeal in their absence? And most importantly, would the journeymen produce a full day's quota of commercially acceptable reams? Lalande doubted it, so he rejected this split regimen and declared that "it would be desirable to be able to oblige [the workers] to do [an ordinary day's labor] in 15 hours" in one exhausting session. ${ }^{63}$

Masters and men were keenly aware of the hour when work was supposed to begin, and, as the Thiernois strike demonstrated, it was the bold manufacturer who tried to alter it. The Dutch workday began at 3:30 a.m., and at the Rannersdorf mill in Austria, the vatman picked up his molds at 4:00 a.m. ${ }^{64}$ Across the Atlantic, an American apprentice remembered that from January until May he awoke at 2:00 a.m. He made a fire to warm the vat, roused the skilled veterans, and later, blew "a horn to notify all the men in the mill to Come and help press the [paper]." ${ }^{, 65}$ In Spanish papermaking, apprentices squeezed around the stamping hammers and troughs from midnight to 3:00 a.m. to gather soiled, caked fibers before the start of the vat crew's toil. ${ }^{66}$ In England, as noted above, the papermaking day commenced at the relatively late hour of 6:00 a.m. ${ }^{67}$ Why the eighteenth-century English industry diverged from the Continental custom of night work remains unknown. A 6:00 a.m. start was common in many English trades, but the paperworkers, with their tightly coordinated tasks and physically demanding labor, tended to work slightly shorter days than some craftsmen and millhands. In fact, their nineteenthcentury heirs, the tenders of papermaking machines, worked longer hours than the journeymen who had once sweated around the vats.

In 1792, the vatmen, couchers, and laymen at Whatman's Turkey Mill were expected to work for twelve hours per day across a six-day workweek. ${ }^{68}$ Polish 
paperworkers and the vast majority of their French and American counterparts shared this regimen. ${ }^{69}$ At the Worblaufen and $\mathrm{Zu}$ Thal mills of Berne, where the journeymen evidently began their toil at 3:00 a.m., workdays stretched from twelve to fourteen hours, with some sort of "break" for the vatmen and couchers. ${ }^{70}$ Work around the vats in the Rannersdorf mill regularly lasted for a fatiguing fourteen hours. ${ }^{71}$ Such comparisons, it must be noted, are less exact than they appear. English paperworkers, for instance, sometimes took an hour and a half break for meals, but they were also known to eat while laboring around the vats. At the Montgolfier mill in Annonay, however, the influential and calculating masters engineered particularly precise workdays punctuated by equally precise mealtimes. The governor of the beaters sounded the bell at 3:45 a.m. and work began at four, a departure from convention that the producers of Thiers could only envy. The day's labor was divided into four segments, each capped by a meal, and ended at 7:00 p.m. Étienne Montgolfier claimed that the "effective" workday in the family's shops was thirteen hours. Seasonal light mattered little in the mill, since the Montgolfiers joined their Auvergnat confrères and ignored the longer summer workdays prescribed by the state in 1739. Just to be sure, the Montgolfiers computed the precise hours of candlelight needed in their mill from mid-August to the end of April; December, for example, required six hours and forty-five minutes worth of candles. $^{72}$ Theirs may have been an unusually mathematized, Enlightened approach to secure regular diligence and output, but it was less audacious because of the well-established production regimens of their trade.

If most paperworkers' days were somewhat less mechanical than those endured by the Montgolfiers' hands, their "day's work" was every bit as exact. In Angoumois, the informed inspector of manufactures Nicolas Desmarest reported that the everyday workload "always" amounted to twenty posts of paper, the measure of newly made sheets still attached to the felts. ${ }^{73}$ In England, the customary day's work was also twenty posts. This quota was so widely ingrained in the English trade that the Combination Act of 1796, which called into question much of the industry's contested custom, still specified that "twenty of which posts shall and do make a day's work." Over time, the seasoned vatman learned how often per minute he had to dip his mold in the pulp to build a proper post. And while the vatman was shaking his mold to smooth the infant sheet and drain it, the coucher was returning a second mold to him, which had just been freed of its newly minted sheet. This became an intense, familiar time discipline. Thus the Combination Act mandated that "the time of working by journeymen at the vat ... shall be half an hour about each post." 74 The Montgolfiers' hands even launched a complaint by indicating themselves the exact amount of time it took to produce a post. ${ }^{75}$ Perhaps masters once had to impose the day's work of twenty posts on recalcitrant journeymen; but by the eighteenth century, the paperworkers in England and France had internalized this standard. After all, it provided them with a firm base from which to haggle with their bosses and insulated them from the ambitions of predatory masters. 
To make this system effective, the time and effort necessary for the creation of every post had to be held constant. Since printers and stationers demanded many types of paper, the number of sheets in each post was the subject of careful consideration. Accordingly, in England, twenty posts of the lightweight paper known as "pott" produced slightly more than thirteen reams, while twenty posts of the demanding "imperial" furnished slightly less than three and a half reams. In Angoumois, the posts included as few as 53 to as many as 264 sheets (and the felts that separated them), permitting a foreman to measure output at a glance. ${ }^{76}$ And whether he was located in Kent or the Vivarais, the foreman would have known that his distant competitors' posts ordinarily matched his in size and content. The everyday mathematization of the killing work of hand papermaking and its industrious demands took shape within a fabric of durable, customary measures.

At the end of the eighteenth century, English paperworkers expected to produce as much as eight "day's work" in six or six and a half workdays. Seemingly contradictory, this balance rested on the definition of the "day's work" as the fabrication of twenty posts. Additionally, the vat crews routinely fashioned extra sheets to compensate the master for spoiled paper. A determined team might also produce reams "à l'avantage" in France, that is, beyond the conventional "day's work." But in Rannersdorf, the rewards for "overwork" were determined by both the excess hours the journeymen labored and the number of reams and sorts of paper they produced. Rannersdorf's masters counted on the journeymen's superhuman effort in order to take advantage of seasonal waters free of sand. ${ }^{77}$ All overtime labor, then, should not be attributed to a newfound industriousness among the workers. In fact, the boundaries of choice and coercion were often blurred by necessity. And the journeymen were more likely to be consumed by this extra effort than use it to consume novel goods.

To the delight of manufacturers everywhere, the pursuit of overtime premiums may have prompted the journeymen to complete their routine "day's work." This incentive, however, had its dangers. Fearing heaps of shoddy paper, the French state prohibited the manufacture of reams " $a$ l'avantage" in $1739 .^{78}$ Lalande celebrated this ban, since he believed that "there is nothing easier in the making of paper than to do a great deal of work and do it badly."79 Across the Channel, the masters' cartel of Kent recommended in 1803 that their brethren "permit no day's work of paper ... to be executed in less than 10 hours." 80 As a means of meeting the rapidly rising appetite for paper at the close of the Old Regime, overtime rewards had real limits. Yet as a means of swelling the purses of masters and men, they had their temptations. So long as "overwork" did not leave its mark in the paper, experienced manufacturers and journeymen both realized that it paid off. But did overtime labor represent a new spirit of industriousness in the trade or the immemorial practice of pursuing higher profits and earnings during periods of surging demand? Even the women who labored on call ("worked by agreement") in the paper mills of Berne were entitled to "overwork" payments. ${ }^{81}$ Like their husbands and 
brothers, these women were discarded as soon as the need for their skills ceased. Thus a realistic and affecting assessment of the workforce at an English mill late in the eighteenth century explained that beyond the usual number of men in the shops, there were "sometimes more, sometimes less, sometimes girls, sometimes women, and sometimes men." 82 Overtime work, then, may have served the journeymen and their families as a hedge against the inevitable lean times of their trade.

Since journeymen paperworkers were highly conscious of the value of their time and their overtime, they expected compensation when the everyday troubles of their trade stopped their work. Kent's producers "agreed to find work for their men for six days per week and 'when short of water to find them other employment equivalent thereto.",83 At Rannersdorf, when "some hitch" stopped papermaking, the vat crews received their regular weekly wages and an additional twenty Kreutzer, since they were "deprived of the advantage of piecework," that is, the payment for meeting their daily quotas. ${ }^{84}$ In the Vosges, paperworkers at one mill received a half-day's wage when a drought or a freeze idled them. When the problem was scarce rags, a manmade deficiency, the journeymen were entitled to a full day's pay. ${ }^{85}$ Such compensation, even makework, was unusual in an era when shutdowns generally drove both the skilled and unskilled to the road. But rags rotting in the pourrissoir, the promise of seasonal rains, and the journeymen's successful efforts to limit their numbers sometimes compelled papermakers to cling to their core hands. As one inspector of manufactures explained, "Want of a single [member of the vat crew] halts the work of three." 86 To anchor their key men, the manufacturers coughed up a few sous and hoped for the speedy end of a drought or the quick repair of a cracked vat-and as soon as the papermaking season closed, they sent the rest of the journeymen packing.

Master papermakers often provided housing for the journeymen and always charged them for it. Two vatmen at the Rannersdorf mill, for instance, each paid eight Gulden a year for two rooms and a kitchen. ${ }^{87}$ Fortunate paperworkers were warmed by fireplaces, slept on straw mattresses, and even had stiff bedlinen. But for many, living quarters amounted to pallets in airless, dank chambres. Perhaps these spaces surpassed the cold ground of the open road, but too often just barely. So it was more likely the promise of food (and cash wages) rather than the appeal of most mill lodgings that enticed journeymen.

The "master's table" was a prominent fixture in most early modern European paper mills. According to the manufacturers, it was also the site and source of turbulence and complaint in every mill. It was an integral element of the reward system: Lalande estimated that veteran French workers earned 120 livres in wages per year and consumed 180 livres worth of food. ${ }^{88}$ Of course, the routine collapse of production in many mills means that such figures actually disclose the place of food in the balance of the journeymen's earnings. Still, the "master's table" may have insulated the paperworkers from shocks in the movement of food prices. And this fixture permitted the journeymen to accord rank and distinction without the masters' approval. Both the 
apprentice and the newly minted journeyman had to treat veteran hands for the right to join them at the table. When work ceased for such celebrations, the patrons fumed: Too many costly walkouts, they knew, had their roots in the illicit as well as the licit customs of the mill table. Perhaps this tumult explains why Austria's manufacturers transformed the "master's table" into a "daily board allowance," and even commuted the provision of traditional holiday delicacies into cash payments. ${ }^{89}$

French journeymen had clear expectations about the amount and quality of their regular and holiday diets. On the basis of the Montgolfiers' accounts, Marie-Hélène Reynaud carefully calculated that the Montgolfiers' journeymen consumed 3,931.5 calories worth of food each day. ${ }^{90}$ Judging by the scale used by Robert Fogel, this level of nutrition was likely ample for a full day of papermaking. So Fogel's important conclusion that comparatively well-fed English workers were more capable of longer days of more industrious work than their French counterparts does not appear to hold, at least among the paperworkers. $^{91}$ At the moment, we know far less about the nutrition and foodways of England's paperworkers, perhaps because of the relatively late emergence of their custom or simply because they were English. One should also be wary of Reynaud's calculations and the Montgolfiers' claims - their journeymen described the bacon as the "scraps from the sack," noted that the wine gave them "a lot of diarrhea," and that "everything" the masters provided was "contrary to our health." 92 Evidently, consuming sufficient calories for industrious labor was one thing and actually enjoying a higher standard of living during the industrious revolution was another.

In 1776, Josiah Wedgwood, the famous porcelain maker, raged, "Our men have been at play 4 days this week, it being Burslem Wakes. I have rough'd and smoothed them over, \& promised them a long Xmass, but I know it is all in vain, for Wakes must be observed though the World was to end with them."93 Wedgwood's outburst reminds us that formal holiday calendars conceal as much as they reveal. Observance remained local: Even the fiery Wedgwood and his workshops were ensnared in nets of tradition he could not shake off. That said, historians generally agree that the Reformation reduced the number of English workdays lost to religious observance and thereby enhanced production and profits. In 1794, an informed pamphlet claimed that English paperworkers had eleven full days of worshipful respite and twenty-seven workless half-holidays. ${ }^{94}$ In Old Regime France, the journeymen paperworkers sacrificed forty to forty-five workdays to religious observance, and this total does not include the numerous local Saints' Days. (Moreover, it was notoriously difficult to get paperworkers back on task after these breaks.) By the eve of the French Revolution, however, ambitious reformers, including the most elevated churchmen, had evidently shaved the number of fêtes throughout Catholic Europe. ${ }^{95}$ And the Concordat of 1801 drew the holiday calendars of France and England much closer. After this accord, the master papermakers around Paris limited their hands to eight days of worship, including Sainte-Croix, the fête patronale of the trade. ${ }^{96}$ (The journeymen, no doubt, continued to attend 
local fairs and venerate supposedly discarded holidays in church and tavern.) So the English advantage of lengthier workyears probably continued, though diminished, during the long eighteenth century. Meanwhile, as the plight of the Languedocian manufacturers mentioned earlier suggests, holiday downtime was only one among many causes of idled vats. In 1738, an English official lamented the "many Interruptions" of paper production. He took note of "a Redundancy or Deficiency of Water, want of Materials, Intervention of Holy Days, and other Contingencies." 97 These "Contingencies" persisted through the era of hand papermaking, while the demand for paper soared.

\section{Intensifying Conflict}

When relations between the journeymen and paper manufacturers turned bitter in Old Regime France, the workers took up collections for brothers jailed for defending their customs. In England, a fund insulated the journeymen who had to "leave for wages or customs." ${ }^{\text {"98 }}$ Papermakers throughout Europe had long fumed about the journeymen's lively, self-interested preservation of their ways, as well as their willingness to invent new traditions. At the close of the eighteenth century, English manufacturers even depicted themselves as the guardians of the status quo, denouncing the workers' "adoption of a regular system of constant encroachment on the fair and established customs and usages of the trade." ${ }^{99}$ In order to put a brake on the journeymen's creativity, the master papermakers resorted to the "document," or blacklist. But the journeymen had an answer, their own "cards of freedom," which ensured that the properly initiated-and their custom - retained a place in the trade. ${ }^{100}$

To curb the paperworkers' restless expansion of their customs, the Montgolfiers, in 1780-1781, took a daring step: They installed a new system of labor discipline along with their Hollander beaters. They carefully trained young men innocent of the journeymen's customs to labor within their nouvel ordre. Perhaps the construction of the Dutch engines unsettled the old hands; the Montgolfiers' attempt to "curtail their autonomy" certainly provoked them to take action. When the veteran workers refused to toil beside the newcomers and stalked out, the Montgolfiers locked out the defiant men. For a time, the Montgolfiers enjoyed unusual sway in their shops; but they watched vigilantly for any sign of the return of the workers' custom. Like Josiah Wedgwood, they dreamed of making "such Machines of the Men as cannot Err."101 They invested countless hours in the creation of mill codes, incentives, and deterrents. Their rules had a well-oiled precision, and they were tireless in their pursuit of steady, high-quality production. Put simply, the Montgolfiers did not attempt to intensify work; instead, their nouvel ordre stressed regular, predictable results at largely familiar levels. ${ }^{102}$

At the bottom line of persistence and productivity, the Montgolfiers obtained much of what they desired. Their new hands remained in their employ for years, a pattern of stability rare in the industry. These workers also endured relatively long workyears. From 1799-1805, with the exception of the 
troubled year of 1803, the five vat crews at their mill, Vidalon-le-Haut, averaged 247.8 workdays per year. Even in the slow year of 1803, the teams still averaged 210 days of work. ${ }^{103}$ If the Montgolfiers had not quite transformed their workshops into living Encyclopédie plates, the mill had assumed more of the mechanical nature of these illustrations. Few French producers, however, tried to emulate the Montgolfiers' complex new regime. No doubt these manufacturers believed they could not match the Montgolfiers' international markets, network of rag suppliers, and access to the favor of successive political figures. And word doubtless spread that the passing of the willful patriarch, Pierre Montgolfier, his mathematically inclined son, Étienne, and the first generations of their new men marked the gradual reappearance of the journeymen's traditions at Vidalon-le-Haut, just as the revival of the workers' venerable customs at Josiah Wedgwood's potbank followed his death. ${ }^{104}$

In 1794 and 1796, the National Convention and the Directory, respectively, outlawed the paperworkers' association and custom, evidently with no more success than reams of edicts dating back to the seventeenth century. To use the language of Michel Foucault, the journeymen's skills, customs, and capacity to turn the workshops into contested ground had survived the invasive, disciplinary gaze of their masters and the French and English state. Accordingly, an improving Austrian papermaker, Ignaz Theodor von Pachner, tried a different strategy. To make the Empire "independent of the seemingly indispensable 'foreign' types and qualities" of papers, he founded a large mill in KleinNeusiedl in 1793. He furnished this enterprise with the best tools and machines of the day, including Hollander beaters. He expected his hands to turn out six reams of medium paper each day, a familiar rate throughout the European craft. But he concluded that the reams produced in the early morning by the light of flickering candles or the burning of soot-laden woodchips were inferior. So, he reduced the workday in Klein-Neusiedl. Previously, these hours had apparently matched one old Austrian formula of labor from 2:00 a.m. to 7:00 p.m., with a two-hour midday break. Under von Pachner, the mill's regimen lasted twelve hours, from 6:00 a.m. to 6:00 p.m. The work in his shops intensified as the hours of labor diminished. And the Emperor found the elegant features of his paper convincing; he converted the working hours of the industry across his realm at 6:00 a.m. to 6:00 p.m. Had the workers been consulted about these changes? Did they rebel against the new regime? There is no evidence on either count. But under the pressure of the competitive international market for fine paper, it is intriguing that von Pachner had embraced one facet of de Vries's industrious revolution - intensified workat the expense of another when he cut the journeymen's hours. ${ }^{105}$

Beginning in 1815, von Pachner supplied bank-note paper to the newly minted Austrian national bank. It was said to rival the paper furnished by the Turkey Mill in Maidstone, which had been in James Whatman's hands until his death in 1798. (Perhaps the desire to emulate Whatman's wares in Austria led von Pachner to mimic the daylight hours of labor in England's mills.) During Whatman's early years in the craft, the printer and publisher T. C. Hansard explained in 1835, "each individual [paperworker] stood singly; no 
associations were then in existence; and the employer could exact from the labourer a just return for the wages paid him."106 Hansard imagined a gentle world of friendly negotiations between master and man, with respectful deference paid to the manufacturers. In practice, the grievances between masters and men were settled in a "bull ring." The manufacturer sat on a box surrounded by his workers, and the circle was not broken until the dispute was resolved. Once the truce had been reached, whichever side called the meeting provided beer for all. ${ }^{107}$ In the close environment of a one-vat mill, the clash of hard feelings over wages and customary expectations no doubt had to be cooled with beer.

To control their ranks, English paperworkers, like their French counterparts, labored to maintain a balance of one apprentice per vat. They also favored their sons for these spots, but added a distinctive twist: Eldest sons did not require formal indentures, while second sons and candidates from outside the trade did. While the perpetual measure of productivity, the "day's work" of twenty posts, remained the same in France and England, the rest of the trade's custom evolved along distinct as well as intertwined paths. Still, we know much less about English ways before an intense dispute broke out in 1788 .

When the journeymen paperworkers of south Lancashire demanded a wage hike, their employers turned to print. The indignant manufacturers explained that their hands were paid more and enjoyed "more consistent Employment" than "most other Artificers or workmen." The masters also revealed their Achilles heel-their men earned "from 10s [shillings] 6d [pence] [per week] and upwards, according to their Merit."108 Here was an echo of Whatman's world of personal arrangements between master and man. Such bargains prevented solidarity among the masters about wage levels. Instead, they poached skilled hands from each other, resorting to higher wages rather than reduced hours or production quotas. As word got around about desperate masters or soft touches, the journeymen built their combination. They banned native "blacklegs" who had avoided apprenticeship or were willing to work for less, as well as low-paid Scottish and Irish journeymen. In 1790, a paper manufacturer in Hertfordshire had eleven hands tried "for a conspiracy to raise their [weekly] wages."109 A producer in Kent spoke of an "alarming State of Trade in consequence of the daring Combinations formed and forming between the Men of different Counties." 110

In 1796, Parliament outlawed the paperworkers' combination. At the urging of several paper manufacturers, however, this Act failed to follow the long line of statutes that set wages in other trades. These producers feared that an Act that destroyed "all Emulation among the Workmen" for personal gain would harm their efforts to tame the journeymen's association. ${ }^{111}$ Yet the prevailing approach among the masters was changing in the Revolutionary era. In 1797, the manufacturers of Kent proposed a general reduction in the wages of their journeymen. The entire body of paperworkers walked out, forcing the masters to relent. Makers of high-quality reams, the Kentish paperworkers were accustomed to wages twenty percent higher than their brothers elsewhere. This distinction did not loosen the bonds within the national paperworkers' combination; instead, it 
encouraged paperworkers throughout England to seek Kentish wages and customs. In 1801, the master papermakers of Kent and Surrey claimed that "[i]t had been hoped ... to have met these temporary difficulties [the increasing cost of rags, wages, and excise duties] through the united skill and efforts of the masters, assisted by the care, attention, and steadiness, of their workmen." 112 Now they knew better. These masters formed an illegal cartel, and in 1803, this cabal served as one base of the equally illegal United Society of Master Papermakers of Great Britain. (Scottish and Irish workers had demanded higher wages, too.) The days of the "bull ring" were coming to an end; but, faced with rising unit costs of production and tempted by rising demand for their paper, late eighteenth-century European manufacturers could neither coerce nor seduce the journeymen to abandon their familiar day's work. European papermakers confronted nineteenth-century demand within seventeenth- and eighteenth-century output schedules. A deft vat crew's production of five reams per day of the paper known as "royal blue," still the order of the day at the turn of the nineteenth century, would no longer suffice. It was the absence of an industrious revolution in hand papermaking that paved the way for the papermaking machine.

\section{The Coming of the Papermaking Machine}

In 1766, a Swiss calico printer considered the place of England in technological change and refinement: "[T]hey cannot boast of many inventions, but only of having perfected the inventions of others; whence comes the proverb that for a thing to be perfect it must be invented in France and worked out in England." ${ }^{113}$ Whether this was generally true is beyond the scope of this essay. But the calico printer's claim does fit the course of the invention and improvement of the papermaking machine. While observing the ceaseless conflict between the manufacturers and journeymen at a mill in Essonnes, Nicolas-Louis Robert began work in 1798 on his papermaking machine. His invention centered on a ceaseless, rotating web of wire mesh and was designed to mimic the journeymen's skills, surpass their productivity, and end their mastery of the shop floor. If technological curiosity and "industrial Enlightenment" contributed to Robert's inventiveness, he made it clear that he was driven by his desire to overturn the powers that grew out of the journeymen's skills. ${ }^{114} \mathrm{He}$ even imagined that "the work of operating the machine can be done by children." 115 During the first years of the nineteenth century, the mechanical engineer Bryan Donkin crafted a commercially viable version of this device in Bermondsey. ${ }^{116}$ Since proverbial wisdom is not a substitute for explanation, I have chosen to cast my interpretation of England's technological primacy in mechanized papermaking at least partly in the language of industriousness, that is, time and work. More precisely, I suggest that England's papermaking advantages were as large as the workyear while France's edge was inscribed in the confines of the workday. And it was these workyear strengths that enabled England to overcome France's workday advantages and become the first center of the mechanized art. 
During the long century that began in 1680, the skills and instruments of English papermaking caught up with cutting-edge Continental practice. The critical, year-round elements in this process were many and diverse. They ranged from the advanced state of English industrial engineering and metaland wireworking to the physical concentration of the industry (when compared to the more diffuse French trade), which likely encouraged the quick adoption of new devices. Of particular importance were Parliament and the Treasury's effective promotion and protection of papermaking (including wartime restraints on the importation of French reams) and the masters' relative lack of dependence on state capital for technological improvement. England's distinctive practices and institutions of technological reception, from the rapid integration of Huguenot masters and journeymen to the remarkably open membership of the Royal Society of Arts, improved the processes and products of the industry. Finally, despite the usual afflictions of fire, flood, and rag shortages, widespread use of Dutch engines and limited Feast Days also added some work time to the English papermakers' lead. Thus, a Protestant ethic of industriousness did not distinguish English papermaking from its cross-Channel rival; instead, it was a set of material, financial, institutional, and political advantages that spanned the workyear.

The technology of English papermaking began to advance beyond the Continent's during the last years of the eighteenth century. Vibrating tirelessly, the mechanical duster, a rotating wire cage animated by the mill's power train, cast off dirt and dust from cast-off linen. It spared the lungs of the women workers it replaced, but made its way slowly across the Channel. The hog, the colorfully named mechanical agitator, also appeared in English mills first. It prevented the pulp from settling in the vats, and thereby freed the masters from dependence on youngsters bored by the tedious labor of stirring up the material twenty to forty times each day. English producers also turned quickly to the hydraulic press, a device capable of imposing considerably more pressure on drying paper than the familiar screw press. Taken together, these second-level technological departures saved time and labor costs and taught English papermakers the art of blending machines with a product easily damaged by rough handling. But they offered neither the prospect of intensified productivity beyond the venerable "day's work" nor the means to challenge the journeymen's customs.

For its part, French papermaking continued to enjoy the workday advantages of skill and touch. It also had workyear strengths of less costly rags and (from the masters' vantage) less expensive labor. The papermaking machine, however, was geared to produce good quality paper in massive quantities. It stripped French papermaking of its workday advantages of elegance and long experience, although the market for distinctive handmade sheets never disappeared. While the diffusion of this device only added to the transnational problem of securing deep supplies of discarded linen, it undermined the French workyear advantage of comparatively low wages. Even the first machines did the work of eight vat crews. Still technological refinement is often a 
slow process: In the case of the papermaking machine it took years of marketand power-driven effort as well as the cumulative workyear advantages of the English industry to accomplish it.

The pulse of the machine introduced neither time discipline nor industrious production into papermaking. In many ways, the transnational "day's work" of twenty posts had reconciled the pressures for steady productivity with the manufacture of quality reams. The trade's distinctive piece rate, with rewards for quota-making as well as "overwork", reflected the need to both hurry up and take it easy in the course of production. With the notable exception of their desire to start work at the proper time, just before dawn, the journeymen fought more to preserve and expand their customs and wages than about time itself. The papermaking machine both drew on and unraveled an enduring web of industrial work, its custom, its compensations, and its time.

\section{A Concept Too Many?}

In 1983, D. C. Coleman summarily dismissed protoindustrialization as "a concept too many." "117 Since the spread of handicraft textile production failed to predict the diffusion of its mechanized successors, Coleman concluded that the new paradigm was merely the artifice of sociologically inclined historians. After all, the concept neither pinpointed the geographical origins of modern industry nor explained why it arose in certain regions. But Coleman's reproach was too comprehensive. For instance, the historians of protoindustrialization did valuable archival and interpretive spadework about urban-rural production networks in early modern Europe. They also offered beguiling and toughminded assessments of the veillées (evening gatherings) and by-employments that carried villagers through the dark winters of northern Europe.

For the historian of early modern European papermaking, it would be equally easy to dismiss summarily de Vries's depiction of an industrious revolution during the long eighteenth century. The evidence of longer hours and newly intensified work in the mills is either paper thin or altogether absent, and paid labor for all members of papermaking households had old roots. The virtuous circle of demand- and supply-side explanations in the coming of large-scale industrialization, as de Vries described it, failed to take shape in papermaking. Instead, it was the limited prospects for fresh industriousness in hand papermaking that led manufacturers and engineers to search for a mechanized alternative.

But just as attention to protoindustrialization opened new avenues of inquiry, de Vries's paradigm has also prompted creative research and reconsideration. Hans-Joachim Voth's ingenious use of English court records is the most compelling of these studies. Essentially, he mined the testimony of Londoners to reveal what they were doing when they witnessed crimes. On this (somewhat indirect) basis, he concluded that the city's laboring classes expanded their year's work by twenty percent during the latter half of the 
eighteenth century. Yet, Voth's account of the motives behind this increase remains incomplete: Did these growing hours of toil reflect new consumer aspirations or the press of desperation, or as times changed, both? ${ }^{118}$ And since the English state ceaselessly raised taxes on a wide variety of goods, did Londoners labor more hours simply to stand still as consumers $?^{119}$ De Vries himself has mocked the emphasis on the working poor's increasing consumption of beer and tobacco during the long eighteenth century as an "Andy Capp" caricature of the era's consumer revolution. ${ }^{120}$ (His model centered more on household purchases of goods manufactured elsewhere, such as mirrors and tortoiseshell combs.) But late afternoons of ribaldry, smoking, and drinking wine or beer surely cemented the solidarity among journeymen paperworkers and allowed tramping men to learn the location of an opening and earn the right to it. Often, these were the ties that bound-and prevented hunger or worse. Here were the moments when the tramping man found out where to pawn a pearl-handled knife or trade it for food, just as his distant ancestors likely had. We still need evidence of the precise links between whatever new patterns of consumption emerged during the long eighteenth century and measurable shifts in the pace and duration of labor, especially in large workshops and manufactories. Only then can we assess what was revolutionary or even newly "industrious" about the drives and efforts of early modern Europe's skilled industrial hands before they were overpowered by the mechanization of their arts.

\section{NOTES}

1. Early American Papermaking: Two Treatises on Manufacturing Techniques, reprinted from James Cutbush's American Artist's Manual (1814) with an Introduction by John Bidwell (New Castle, DE, 1990), 31. The quoted phrase is Bidwell's. On the general issue of early modern European worktime, see Corine Maitte and Didier Terrier, "Une Question (re)devenue central: Le temps de travail," Genèses 85 (2011): 156-70; Corine Maitte and Didier Terrier, eds., Les temps du travail: Normes, pratiques, évolutions (XIVe-XIXe siècle) (Rennes, 2014); Craig Muldrew, Food, Energy and the Creation of Industriousness: Work and Material Culture in Agrarian England, 1550-1780 (Cambridge, 2011); Sidney Pollard, The Genesis of Modern Management: A Study of the Industrial Revolution in Great Britain (Cambridge, MA 1965); E. P. Thompson, Customs in Common: Studies in Traditional Popular Culture (New York, 1991), 352-403; and Hans-Joachim Voth, Time and Work in England, 1750-1830 (Oxford, 2000). For a modern comparison, see Michael Huberman, "Working Hours of the World Unite? New International Evidence of Worktime, 1870-1913," Journal of Economic History 64 (2004): 964-1001.

2. Jan de Vries, The Industrious Revolution: Consumer Behavior and the Household Economy, 1650 to the Present (New York, 2008). For de Vries's most influential articles on the industrious revolution, see "Between Purchasing Power and the World of Goods: Understanding the Household Economy in Early Modern Europe," in Consumption and the World of Goods, ed. John Brewer and Roy Porter (London, 1993), 85-132; "The Industrious Revolution and Economic Growth, 1650-1830," in The Economic Future in Historical Perspective, ed. Paul David and Mark Thomas (Oxford, 2003), 43-71; "Economic Growth before and after the Industrial Revolution: A Modest Proposal," in Early Modern Capitalism: Economic and Social Change in Europe, 1400-1800, ed. Maarten Prak (London, 2001), 177-94; and "The Industrial Revolution and the Industrious Revolution," Journal of Economic History 54 (1994): 249-70. On the industrious revolution, see also Jean-Yves 
Grenier, "Travailler plus pour consommer plus: Désir de consommer et essor du capitalisme, du XVIIe siècle à nos jours," Annales: Histoire, Sciences Sociales 65 (2010): 787-98; Gregory Clark and Ysbrand Van Der Werf, "Work in Progress? The Industrious Revolution," Journal of Economic History 58 (1998): 830-43; and Robert C. Allen and Jacob L. Weisdorf, "Was There an 'Industrious Revolution' before the Industrial Revolution? An Empirical Exercise for England, c. 1300-1830," Economic History Review 63 (2010): 1-15. On intangible "goods," see John Brewer and Frank Trentmann, "Introduction: Space, Time and Value in Consuming Cultures," in Consuming Cultures, Global Perspectives: Historical Trajectories, Transnational Exchanges, ed. John Brewer and Frank Trentmann (Oxford, 2006), 1.

3. On French papermaking, see Louis André, Machines à papier: Innovation et transformations de l'industrie papetière en France, 1798-1860 (Paris, 1996); Henri Gazel, Les Anciens Ouvriers papetiers d'Auvergne (Clermont-Ferrand, 1910); Pierre-Claude Reynard, Histoires de papier: La papeterie auvergnate et ses historiens (Clermont-Ferrand, 2001); and Leonard N. Rosenband, Papermaking in Eighteenth-Century France: Management, Labor, and Revolution at the Montgolfier Mill, 1761-1805 (Baltimore, 2000). On English papermaking, see Thomas Balston, James Whatman, Father and Son (London, 1957); D. C. Coleman, The British Paper Industry, 1495-1860: A Study in Industrial Growth (Oxford, 1958); Richard Hills, Papermaking in Britain, 1488-1988: A Short History (London, 1988); A. H. Shorter, Paper Mills and Paper Makers in England, 1495-1800 (Hilversum, 1957); Jean V. Stirk, Industrial Relations in a Craft Trade: The Original Society of Papermakers, 1800-1948 (Ph.D. diss., London School of Economics and Political Science, 1999).

4. For the specific citations concerning worktime in papermaking, see below.

5. The clearest account of de Vries's formulation of the concept of industrious revolution is in his essay, "Between Purchasing Power and the World of Goods." 85-132.

6. Cissie Fairchilds, "The Production and Marketing of Populuxe Goods in Eighteenth-Century Paris," in Consumption and the World of Goods, ed. John Brewer and Roy Porter (London, 1993), 228-48.

7. For this new "disposition," see de Vries, "Industrial Revolution and Industrious Revolution," 262.

8. For "market-oriented labour," see de Vries, "The Industrious Revolution," 53.

9. Certainly, the concept of protoindustrialization is essential to de Vries's depiction of the industrious revolution. (Franklin Mendels coined the term protoindustrialization in his article, "Proto-industrialization: The First Phase of the Industrialization Process," Journal of Economic History 32 (1972): 241-261.) Protoindustrialization entailed the decentralized production by agrarian households of market-oriented manufactured goods, especially but not exclusively linen and woolen textiles. For de Vries, this process integrated all members of laboring households into the market economy, where they earned wages, often for the first time. The purchasing power of these households grew as men, women, and children chose to work more to consume more. It should be noted, however, that protoindustrial linen and woolen production had lengthy pedigrees before the long eighteenth century. And part of this lineage, according to Craig Muldrew, constituted "a response to falling real wages and labour market competition in the first half of the seventeenth century, which eventually resulted in greater earnings." (Muldrew, Food, Energy and the Creation of Industriousness, 16.) But these gains came under renewed pressure during the second half of the eighteenth century, and many protoindustrial households undoubtedly labored more to remain solvent rather than to indulge in newfound fancies. (Frank Trentmann, Empire of Things: How We Became a World of Consumers from the Fifteenth Century to the Twenty-First (New York, 2016), 74-75.) Moreover, I would add that the complexity of early modern European working relations, in which a petty landowner might toil as a blacksmith at a nearby forge, suggests that attitudes to labor, leisure, and consumption were anything but unitary in the early industrial countryside. (Muldrew, Food, Energy and the Creation of Industriousness, made a similar point, 317).

10. De Vries, Industrious Revolution, 71.

11. On the balance between the demand and supply sides in the making of the industrial revolution, see the still powerful, if somewhat dated, account in Joel Mokyr, "Demand vs. Supply in the Industrial Revolution,” Journal of Economic History 37 (1977): 981-1008.

12. The quoted phrase is in Thompson, Customs in Common, 394.

13. E. J. Hobsbawm, "Custom, Wages, and Work-Load in Nineteenth-Century Industry," in Essays in Labour History, ed. Asa Briggs and John Saville (New York, 1967), 113-39. See also 
Arthur Taylor, ed., The Standard of Living in Britain in the Industrial Revolution (London, 1975). For the most recent estimates of living standards in industrializing Britain, see Charles Feinstein, "Pessimism Perpetuated: Real Wages and the Standard of Living in Britain during and after the Industrial Revolution," Journal of Economic History 58 (1998): 625-58.

14. Pollard, Genesis of Modern Management, 161.

15. David Landes, The Unbound Prometheus: Technological Change and Industrial Development in Western Europe from 1750 to the Present (Cambridge, 1969), 123.

16. On the usefulness of considering wage systems and forms, see Experiencing Wages: Social and Cultural Aspects of Wage Forms in Europe since 1500, ed. Peter Scholliers and Leonard Schwarz (New York, 2004). See also the classic article by Michael Sonenscher, "Weavers, Wage-Rates and the Measurement of Work in Eighteenth-Century Rouen," Textile History 17 (1986): 7-18.

17. Quoted in de Vries, "Industrial Revolution and Industrious Revolution," 259.

18. Quoted in Marie-Hélène Reynaud, Les Moulins à papier d'Annonay à l'ère pré-industrielle (Annonay, 1981), 164.

19. On the Protestant work ethic, see the classic account by Max Weber, The Protestant Ethic and the Spirit of Capitalism, 2nd ed. (London, 2001 [1904]). But see also Amintore Fanfani, Catholicism, Protestantism and Capitalism (New York, 1936) and Matthew Kadane, The Watchful Clothier: The Life of an Eighteenth-Century Protestant Capitalist (New Haven, 2013); on the relationship between food supply and worktime, see Robert W. Fogel, The Escape from Hunger and Premature Death, 1700-2100: Europe, America, and the Third World (Cambridge, 2004); and on the intersections of the Enlightenment and industrial transformation, see Margaret Jacob, The First Knowledge Economy, 1750-1850 (New York, 2014), and Joel Mokyr, The Enlightened Economy: An Economic History of Britain, 1700-1850 (New Haven, 2009). For a rather different take on the influence of the Enlightenment, see Michel Foucault, Surveiller et punir: Naissance de la prison (Paris, 1975).

20. For the influence of French papermaking on the English industry, see the titles in footnote 3. On the general issue of technological transfer during the long eighteenth century, see Christine MacLeod, "The European Origins of British Technological Predominance," in Exceptionalism and Industrialisation: Britain and Its European Rivals, 1688-1815, ed. Leandro Prados de la Escosura (Cambridge, 2004), 111-26.

21. Robert Darnton, The Business of Enlightenment: A Publishing History of the Encyclopédie, 1775-1800 (Cambridge, MA 1979), 193.

22. Nicolas Demarest, "Mémoire pour M. Demarest," Archives Nationales, F12 1479.

23. Coleman, British Paper Industry, 169 Table.

24. Johann Lindt, The Paper-Mills of Berne and Their Watermarks, 1465-1859 (Hilversum, 1964), 49, Table ("Prices of Rags, Paper, and Wages at the Worblaufen and Zu Thal Mills during the Eighteenth and Nineteenth Centuries"), double-starred note.

25. Joseph-Jérôme Lefrançois de Lalande, The Art of Papermaking, trans. Richard Atkinson (Kilmurry, Ireland, 1976), 41. Lalande originally published his Art de faire le papier in Paris in 1761.

26. Ibid., 56.

27. Ibid., 59-60.

28. Georg Eineder, The Ancient Paper-Mills of the Former Austro-Hungarian Empire and Their Watermarks (Hilversum, 1960), 31.

29. Carlo Cipolla, Before the Industrial Revolution: European Society and Economy, 1000 1700, 2nd ed. (New York, 1980), 129.

30. "État des moulins à papier," Archives Départementales de l'Hérault, C 2676.

31. Quoted in Shorter, Paper Mills and Paper Makers, 79.

32. Shorter, Paper Mills and Paper Makers, 236.

33. Ibid., 153.

34. Ibid., 79.

35. On the issue of maintenance, including Woronoff's insight, see Pierre-Claude Reynard, "Early Modern State and Enterprise: Shaping the Dialogue between the French Monarchy and Paper Manufacturers," French History 13 (1999): 1-25; Pierre-Claude Reynard, "Unreliable Mills: Maintenance Practices in Early Modern Papermaking," Technology and Culture 40 (1999): 237-62.

36. H. M. Fiskaa and O. K. Nordstrand, Paper and Watermarks in Norway and Denmark (Amsterdam: 1978), 325. 
37. Hills, Papermaking in Britain, 53.

38. Lalande, Art of Papermaking, 56.

39. As John Hatcher wisely observed, "it is much more likely that favourable movements in wage rates and prices would lead to an increase in both leisure and consumption, an outcome which helps to explain the paradox that the poor in times of high wages and plenty were accused both of refusing to work and consuming more goods." See John Hatcher, "Labour, Leisure and Economic Thought before the Nineteenth Century," Past \& Present 160 (1998): 84.

40. Commissioners for Trade and Plantations, "Paper Manufactr," December 23, 1697, British Library, Sloan MSS, 2902.

41. Quoted in Shorter, Paper Mills and Paper Makers, 58.

42. Coleman, British Paper Industry, 142.

43. Ibid., 91.

44. Ibid., 110-11.

45. For the advantages of technological backwardness, see Alexander Gerschenkron, Economic Backwardness in Historical Perspective: A Book of Essays (Cambridge, MA, 1962).

46. Quoted in Hills, Papermaking in Britain, 67.

47. On the growth of English papermaking during the eighteenth century, chapter 2 of Shorter's Paper Mills and Paper Makers in England is a reliable guide. On taxation and protection, see Coleman, British Paper Industry, chapter 5, and William J. Ashworth, Customs and Excise: Trade, Production, and Consumption in England, 1640-1845 (Oxford, 2003), 247-52.

48. Quoted in John Ehrman, The British Government and Commercial Negotiations with Europe, 1783-1793 (Cambridge, 1962), 57.

49. Reynard, Histoires de papier, 26.

50. Nicolas Desmarest, "Papier (Art de fabriquer le)," in Encyclopédie méthodique: Arts et métiers mécaniques, vol. 5 (Paris, 1788), 548.

51. Pierre Léon, "La Réponse de l'industrie," in Histoire économique et sociale de la France, 1660-1789, vol. 2, ed. Fernand Braudel and Ernest Labrousse (Paris, 1970), 249.

52. Reynard, Histoires de papier, 132.

53. Daniel Roche, The People of Paris: An Essay in Popular Culture in the $18^{\text {th }}$ Century, trans. Marie Evans and Gwynne Lewis (Berkeley and Los Angeles, 1987), 146, Table 5.4.

54. Quoted in Henri Gachet, "Les Grèves d'ouvriers papetiers en France au XVIIIème siècle jusqu'à la Révolution," in Papers of the Twelfth International Congress of the International Association of Paper Historians (Haarlem, 1972), 128.

55. Quoted in C.-M. Briquet, "Associations et Grèves des ouvriers papetiers en France aux XVIIe et XVIIIe siècles," Revue Internationale de Sociologie 5 (1897): 166.

56. Thompson, Customs in Common, 185-351; and Jan de Vries, "Great Expectations: Early Modern History and the Social Sciences," Review 22 (1999): 1. In many ways, the customary practices of early modern European paperworkers resembled those depicted by Adrian Randall, Before the Luddites: Custom, Community and Machinery in the English Woolen Industry, 1776-1809 (Cambridge, 1991).

57. Quoted in C.-M. Briquet, "Associations et grèves," 184.

58. Judith McGaw, Most Wonderful Machine: Mechanization and Social Change in Berkshire Paper Making, 1801-1885 (Princeton, 1987), 53.

59. For the key provisions of the decree of 1688, see Briquet, "Associations et grèves," 167-68. Henri Gazel, Anciens Ouvriers, specifies that the daily workload was fixed at "8 reams of paper weighing 13 livres per ream or 6 reams and 16 quires of 8 livres, or 5 reams, from 18 to 30 livres per ream," 70 .

60. Gazel, Anciens ouvriers, 71.

61. A translated version of the edict appears in Lalande, Art of Papermaking, 73.

62. Briquet, "Associations et grèves," 177-78.

63. Lalande, Art of Papermaking, 73, note b.

64. For Dutch papermaking, see Dard Hunter, Papermaking: The History and Technique of an Ancient Craft, rev. 2nd ed. (New York, 1978 [1947]), 243; and for Rannersdorf, see Eineder, Ancient Paper-Mills, 52.

65. Ebenezer Hiram Stedman, Bluegrass Craftsman: Being the Reminiscences of Ebenezer Hiram Stedman, Papermaker: 1808-1885, ed. Frances Dugan and Jacqueline Bull (Lexington, KY, 1959), 35, 38.

66. Oriol Valls I Subirà, The History of Paper in Spain, XVII-XIX Centuries, vol. 3 (Madrid, 1982), 16. 
67. Hunter, Papermaking, 241-42.

68. Coleman, British Paper Industry, 297.

69. Valls I Subirà, History of Paper in Spain, explained that "the work day in France was twelve hours," 17. He also observed that the same regimen characterized "Italy, Poland, and England." Without explanation, however, he wrote that in Spanish papermaking "there were not set working hours. If meeting a delivery date for an order of paper involved around-the-clock hours, the mill remained working day and night." Of course, paper manufacturers throughout Europe ignored the clock under this pressure, but in France, they feared that the journeymen would hurry through the process and damage "ordinary" work in pursuit of "overwork" bounties. On this point, see Gazel, Anciens Ouvriers, 70, note 1.

70. Lindt, Paper-Mills of Berne, 49, Table, starred note. On the "break," see 56.

71. Eineder, Ancient Paper-Mills, 52.

72. Rosenband, Papermaking, 110. On the Auvergnat industry, see Gazel, Anciens Ouvriers, 70-71. Gazel observed that "the paperworkers [labored] as long in one season as the other, without concern about sunrise or sunset."

73. Desmarest, Papier, 510. Also see the extraordinarily detailed production schedule that Demarest provided for a considerable number of different sorts of paper, 511.

74. The Statutes at Large, 36 George III, c.111, vol. XL, 814.

75. Document 39, Archives Nationales, 131 Microfilm 53 AQ 23.

76. Early American Papermaking, Bidwell's introduction, 33.

77. Eineder, Ancient Paper-Mills, 52-53.

78. Quoted in Lalande, Art of Papermaking, 73.

79. Lalande, Art of Papermaking, 73, note b.

80. Quoted in Thomas Balston, William Balston, Papermaker 1759-1849 (London, 1954), 160.

81. Lindt, Paper-Mills of Berne, 49, Table, double-starred note.

82. Quoted in Coleman, British Paper Industry, 151.

83. Ibid., 298.

84. Eineder, Ancient Paper-Mills, 53.

85. Jean-Marie Janot, Les Moulins à papier de la région vosgienne, vol. 1 (Nancy, 1952), 83.

86. Quoted in Pierre Léon, "Morcellement et émergence du monde ouvrier," in Histoire économique et sociale de la France, ed. Fernand Braudel and Ernest Labrousse, vol. 2 (Paris, 1970), 660.

87. Eineder, Ancient Paper-Mills, 52.

88. Lalande, Art of Papermaking, 60.

89. Eineder, Ancient Paper-Mills, 48, 52.

90. Marie-Hélène Reynaud, "The Daily Life in the Paper Mills of the Montgolfier Just Before the Revolution," IPH Yearbook 8 (1990): 128-35.

91. Fogel, Escape from Hunger, chapter 1.

92. Document 41, Archives Nationales, 131 MI 53 AQ 23.

93. Quoted in Pollard, Genesis of Modern Management, 182.

94. R. Johnson, New Duty on Paper. The Paper-Maker and Stationer's Assistant (London, 1794), unpaginated.

95. Grenier, "Travailler plus. 787-98" See also Noah Shusterman, Religion and the Politics of Time: Holidays in France from Louis XIV through Napoleon (Washington, D.C., 2010).

96. André, Machines à papier, 46.

97. Quoted in Coleman, British Paper Industry, 163, n. 2.

98. Ibid., 266.

99. Quoted in D. C. Coleman, "Combinations of Capital and of Labour in the English Paper Industry, 1789-1825," Economica, new series, 21 (1954): 44 (italics in original).

100. Coleman, British Paper Industry, 262-68.

101. Josiah Wedgwood in 1769 , quoted in Jenny Uglow, The Lunar Men: Five Friends Whose Curiosity Changed the World (New York, 2002), 213.

102. On the Montgolfiers' new regime, see Rosenband, Papermaking, ch. 3 . The quoted phrase "curtail their autonomy" appeared in Catharina Lis and Hugo Soly, "An Irresistible Phalanx': Journeymen Associations in Western Europe," in Before the Unions: Wage Earners and Collective Action in Europe, 1300-1850, International Review of Social History, 39 (Supplement 2) (1994): 51. This phrase is an elegant formulation of Lis and Soly's claim that 
early modern journeymen in a variety of trades were willing to accept limited technological change so long as it did not undo their custom or capacity to bargain.

103. Rosenband, Papermaking, 157.

104. On the course of labor discipline at Josiah Wedgwood's works, see Thompson, Customs in Common, 385-386.

105. Eineder, Ancient Paper-Mills, 45-46.

106. Quoted in Balston, William Balston, 12.

107. On the "bull ring," see Stirk, Industrial Relations, 83, 177.

108. Ibid., 82.

109. Quoted in Shorter, Paper Mills and Paper Makers, 79.

110. Quoted in Stirk, Industrial Relations, 84.

111. Ibid., 86.

112. Ibid., 91.

113. Quoted in Mathias, The Transformation of England: Essays in the Economic and Social History of England in the Eighteenth Century (New York, 1979), 23.

114. As Robert put it, "It has been my dream to simplify the operation of making paper by forming it with infinite less expense, and, above all, in making sheets of an extraordinary length without the help of any worker, using only mechanical means." Quoted in Hunter, Papermaking, 344-45.

115. Ibid., 348.

116. Joel Mokyr argued that "The Industrial Enlightenment then created a set of bridges between intellectuals and producers, savants and fabricants." I would include the journeymen paperworkers in this equation. After all, it was their fingertip know-how, based on experience and observation, that Robert, Donkin, and the manufacturers appropriated and embedded in the papermaking machine. See Mokyr, Enlightened Economy, 54.

117. D. C. Coleman, "Proto-Industrialization: A Concept Too Many," Economic History Review 36 (1983): 435-48.

118. Hans-Joachim Voth, "Time and Work in Eighteenth-Century London," Journal of Economic History 58 (1998): 29-58. See also Trentmann, Empire of Things, 74-75.

119. Ashworth, Customs and Excise.

120. De Vries, "Industrial Revolution and Industrious Revolution," 262. 